\title{
An Immunogenomics Approach to Understanding Periparturient Immunosuppression and Mastitis Susceptibility in Dairy Cows*
}

\author{
By J. L. Burton ${ }^{1,2}$, S. A. Madsen ${ }^{1}$, J. Yao ${ }^{2}$, S. S. Sipkovsky ${ }^{2}$, and P.M. Coussens ${ }^{2}$ \\ ${ }^{1}$ Immunogenetics Laboratory and ${ }^{2}$ The Center for Animal Functional Genomics, Department of Animal \\ Science, Michigan State University, East Lansing, Michigan, USA.
}

\begin{abstract}
Burton JL, Madsen SA, Yao J, Sipkovsky SS, Coussens PM: An immunogenomics approach to understanding periparturient immunosuppression and mastitis susceptibility in dairy cows. Acta vet. scand. 2003. Suppl. 98, 71-88. - Studies comparing in vivo and in vitro functional capacities of leukocytes from non-parturient and periparturient dairy cows have provided substantial evidence that systemic and local mammary immune defenses are deficient around parturition. This evidence has lead to the reasonable hypothesis that immune deficiency underlies the heightened mastitis susceptibility of periparturient cows. Nutrition and vaccine studies substantiate this hypothesis, showing that dietary antioxidant supplementation and rigorous immunization regimes can bolster innate and humoral immunity to the point that mastitis severity and time for return to normal milk production are reduced. However, completely effective resolution of this significant production disease has not been achieved because so little is understood about its complex etiology. In particular, we possess almost no knowledge of how or why immune cells responding to parturient physiology end up with deficient functional capacities. Fluctuations in reproductive steroid hormones and chronic shifts in neuroendocrine hormones with roles in nutrient partitioning and appetite control may affect the expression of critical leukocyte genes in periparturient dairy cows. A thorough understanding of leukocyte biology during periparturition would seem a critical goal for future development of effective mastitis prevention strategies. Recently, our group has begun to use cDNA microarray technology to explore bovine leukocyte RNA for global gene expression changes occurring around parturition. We are working within the context of a hypothesis that the physiology of parturition negatively affects expression of critical genes in blood leukocytes. In the current study we initiated hypothesis testing using leukocyte RNA from a high producing Holstein cow collected at 14 days prepartum and 6 hours postpartum to interrogate a cDNA microarray spotted with $>700$ cDNAs representing unique bovine leukocyte genes. This analysis revealed 18 genes with $\geq 1$.2-fold higher expression 14 days prepartum than 6 hours postpartum. BLASTN analysis of these genes revealed only one that can be considered a classical immune response gene. All other repressed genes were either unknown or putatively identified as encoding key proteins involved in normal growth and metabolism of cells. Given the critical roles of these repressed genes in normal cell functions, we may have identified good candidates to pursue with respect to periparturient immunosuppression and mastitis susceptibility.
\end{abstract}

periparturition; leukocytes; neutrophils; DDRT-PCR; cDNA microarray; functional genomics; gene expression; dairy cattle.

*This contribution was published in Acta vet. scand. 2001, 42, 407-424. 


\section{Introduction}

Despite rigorous management practices aimed at environmental cleanliness, good nutrition, and vaccination, mastitis remains a problem in high producing dairy cows during periparturition (Eberhart 1984, 1986, Erskine et al. 1988, Gonzalez et al. 1988, Hogan et al. 1989, Gonzalez et al. 1990, Hoblet 1991, Erskine \& Bartlett 1995, National Mastitis Council 1996). Periparturient mastitis susceptibility undoubtedly is related to the generalized immune suppression that occurs from approximately 1 week prepartum to 1 week postpartum (Hill et al. 1979, Guidry et al. 1976, Hill 1981, Oliver \& Sordillo 1988, Nagahata et al. 1988, Kehrli et al. 1989a,b, Cai et al. 1994, Detilleux et al. 1994, 1995a,b, Sordillo et al. 1997, Lee and Kehrli 1998, Mallard et al. 1998, Van Kampen et al. 1999, Waller 2000). This scenario can be improved somewhat by dietary supplementation with certain vitamins and minerals (reviewed by Burton et al. 2000) and by dry period vaccination programs (Gonzalez et al. 1989, Hogan et al. 1989, Gonzalez et al. 1990, Cullor 1991, Hogan et al. 1992a,b, Tyler et al. 1992). However, our fight against periparturient mastitis will continue to be incomplete until we find out why cows become immunosuppressed around parturition and discover what genes are responsible for this condition. Once known, expression of these genes could be manipulated through effective dietary supplements, novel pharmacological therapies, and genetic selection strategies to improve mastitis resistance. Of these approaches, genetic selection against periparturient mastitis susceptibility may be the best long-term strategy because it offers the possibility for permanent resolution of this significant disease problem.

Dairy cattle breeders have concentrated on the improvement of milk output and quality at the expense of disease resistance (Freeman \& Lindberg 1993, Funk 1993, Schutz 1994). That the ability of animals to resist infections are, in part, genetically controlled is not a new concept (Legates \& Grinnells 1952). Therefore, selection against mastitis susceptibility is possible (Lindé 1982, Jensen et al. 1981, Lindé 1982, Skjervold 1982, McDnaiel 1984, Solbu 1984, Uribe et al. 1995). Research in this area has a long history and has been focused primarily on determining appropriate traits or markers for genetic selection (e.g., Lie 1977; Lindström \& Syväjärvi 1978, Lie 1979, Lie \& Solbu 1981, Almlid 1981, Lie et al. 1982, Mazengera et al. 1985, Lie et al. 1986, Lewin 1989, Strandberg \& Shook 1989, Vage et al. 1992, Mejdell et al, 1994, Shook 1993, Shook \& Schutz 1994, Detilleux et al. 1994, 1995a, Vecht et al. 1985, Dietz et al. 1997, Kelm et al. 1997, Sharif et al. 1998, 1999, Wagter et al. 2000). In these studies, immune response traits measured in vivo and in vitro usually posses higher heritabilities than mastitis itself, indicating that an animal's level of immunocompetence around parturition may hold the key to identifying genes that make breeding stock genetically superior for mastitis resistance (Detilleux et al. 1994, 1995a,b). However, researchers still have no knowledge of the genes that regulate normal immune resistance against mastitis-causing pathogens, let alone the genes involved in the complex etiology of periparturient immunosuppression that leads to mastitis susceptibility.

To gain clearer understanding of the complexities of periparturient immunosuppression and possible genetic links between these and mastitis susceptibility will require that we dramatically change our experimental approaches to these problems (Madsen et al. 2000, Burton 2001, Yao et al. 2001). Our research group has embraced such change and is now using a holistic functional genomics approach to study endogenous responses of bovine leukocytes to the entire periparturient physiology. In this way, we are allowing leukocytes to tell us their own 
story about what genes are involved in normal immunocompetence and in the suppression of immunocompetence that occurs around parturition (Burton 2001). This paper focuses on our first cDNA microarray analysis of global gene expression changes that occur in bovine blood leukocytes around parturition.

\section{Materials and methods}

Construction of the bovine total leukocyte cDNA library

A detailed description of the development of our bovine total leukocyte (BOTL) cDNA library is given in a companion paper (Yao et al. 2001 , this issue). Briefly, the library was generated from pooled poly (A) ${ }^{+}$RNA isolated from total peripheral blood leukocytes of 4 healthy, mid-lactation Holstein cows. The library was size-selected to eliminate small cDNAs (i.e., $<500 \mathrm{bp}$ ) and normalized to reduce redundancy of highly abundant transcripts (e.g, GAPDH). Over 1,000 colonies of the library were randomly picked (GeneTAC G3 picking robot; Genomic Solutions, Inc.) and subjected to highthroughput DNA sequencing (ABI BigDye terminator sequencing kits and an ABI 3700 automatic DNA analyzer; both from PerkinElmer/ABI, Palo Alto, CA). Resulting clone sequences were trimmed of vector DNA and final insert sequences loaded into our database (http://gowhite.ans.msu.edu) for BLAST (basic local alignment search tool) analysis against the GenBank and TIGR (The Institute for Genome Research) databases.

\section{Production of cDNA microarrays}

The cDNA microarray used for this study con-

Abbreviations: ACD (acid citrate dextrose); BLAST (basic local alignment search tool); BOTL (bovine total leukocyte); TIGR (The Institute for Genome Research). tained triplicate spots for 720 unique cDNAs from our BOTL library and is described in detail in our companion paper (Yao et al. 2001, this issue). Briefly, clone inserts from the BOTL library were amplified directly from bacteria using PCR, purified, and suspended in $17 \mu \mathrm{l}$ of $50 \%$ DMSO for spotting on the microarray (GeneTAC G3 arraying robot; Genomic Solutions, Inc., Ann Arbor, MI). The microarray was spotted with 48 patches (Fig. 1a) each designed in an $8 \times 8$ pattern (i.e., 64 spots per patch) including:

-3 GAPDH spots (a normalizing control for potential RNA loading differences and dye effects; yellow arrow heads in Fig. 1b);

-2 synthetic lambda Q gene spots (positive control; white arrow heads in Fig. 1b), one in the upper right corner of each patch surrounded by 3 blank spots (as landmarks during array image analysis; white box in Fig. $1 b)$;

-16 blank spots (to control for background effects on a patch specific basis; black regions in Fig. 1b); and

-1 spot containing only DMSO (negative control; white circles in Fig. 1b); and

-14 BOTL cDNAs spotted in triplicate (e.g., red and green arrow heads in Fig. 1b).

\section{Experimental Design}

Blood from one periparturient primiparous Holstein cow was used for the current microarray experiment. This cow was housed and cared for at the Michigan State University's Dairy Teaching and Research Facility, and was healthy by all standard measures. Based upon our previous results showing differential expression of numerous genes in blood neutrophils collected prepartum and immediately postpartum (Madsen et al. 2000, Weber et al. 2001), we collected blood from our test cow at day 14 prepartum (d-14) and 6 hours postpar- 

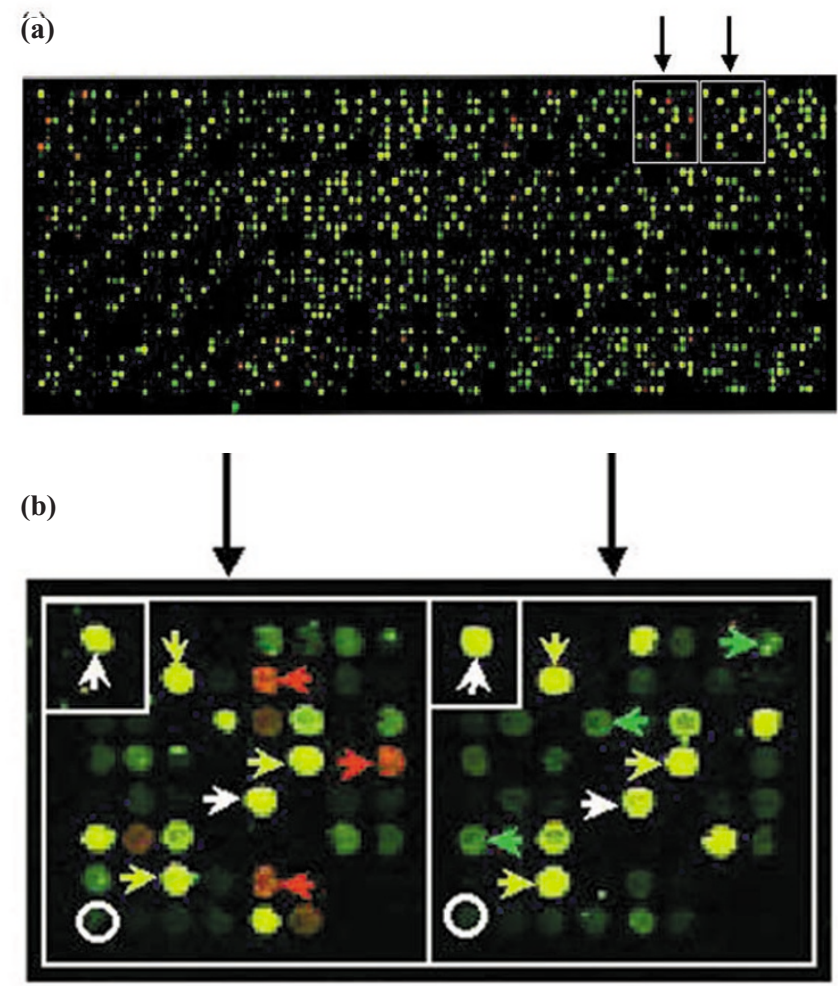

Figure 1. The microarray contained 720 unique bovine cDNAs arrayed in 48 patches across a glass microscope slide (a), each gene was spotted in triplicate within a single patch (b). Each patch was designed as an $8 \times 8$ array of spotted cDNAs originating from our bovine total leukocyte (BOTL) library (see Yao et al., 2001; this issue). Multiple controls were included in each patch as shown in panel (b): 3 GAPDH spots (yellow arrow heads), 2 synthetic lambda Q gene spots (white arrow heads) with one in the upper right corner of each patch surrounded by 3 blank spots (white box), 16 blank spots (black areas), and 1 spot containing only DMSO (white circle). In addition, 14 unique BOTL cDNAs spotted in triplicate were included per patch (e.g., red and green arrow heads in panel b).

tum $(\mathrm{h}+6)$ (Fig. 2). Blood was collected from the coccygeal (tail) vein into a series of four 6$\mathrm{ml}$ evacuated collection tubes (per sample time), each containing $1.0 \mathrm{ml}$ of acid citrate dextrose (ACD) anticoagulant (Fisher Scientific, Pittsburgh, PA). We used 20-gauge, 2.5$\mathrm{cm}$ multiple sample needles (Fisher Scientific) to obtain the blood, which was immediately placed on ice for transport to our laboratory $(\sim 7$ minute drive).
Preparation of leukocytes and RNA isolation Once in the laboratory, chilled blood samples were prepared immediately for RNA isolations. All glassware was DPEC-treated and solutions autoclaved and chilled to $4^{\circ} \mathrm{C}$ for 24 hours prior to use for leukocyte preparations and RNA isolations. Briefly, each $6 \mathrm{ml}$ tube of chilled whole blood was decanted to a sterile $50 \mathrm{ml}$ conical tube preloaded with $30 \mathrm{ml}$ of cold hypotonic lysing solution $\left(10.56 \mathrm{mM} \mathrm{Na}_{2} \mathrm{HPO}_{4}, 2.67 \mathrm{mM}\right.$ 


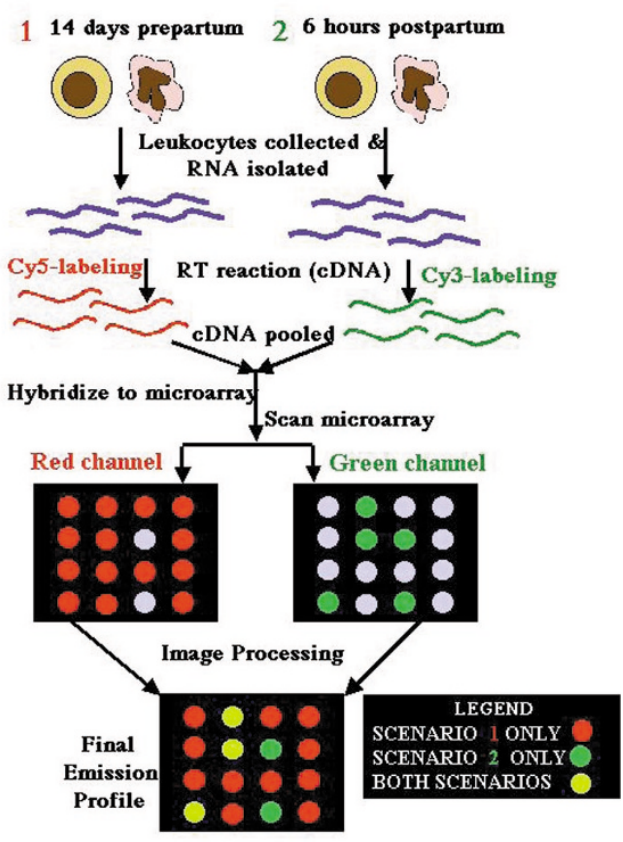

Figure 2. Leukocyte RNA from freshly sampled $\mathrm{d}-14$ and $\mathrm{h}+6$ blood was converted to cDNA by reverse transcription and the cDNAs differentially labeled with Cy5 and Cy3, respectively. The labeled cDNAs were mixed and hybridized to the microarray. After array scanning the Cy5 profile was integrated with the $\mathrm{Cy} 3$ profile to give a final emission profile of red, green and yellow spots (see Figure 1). Red spots represent leukocyte genes preferentially expressed on d-14, green spots represent leukocyte genes preferentially expressed at $\mathrm{h}+6$, and yellow spots represent leukocyte genes expressed equally on $\mathrm{d}-14$ and $\mathrm{h}$ +6 .

$\mathrm{NaH}_{2} \mathrm{PO}_{4}, \mathrm{pH} 7.3$ ), and the tubes gently swirled for 90 seconds to lyse all erythrocytes. Isotonicity was restored in each tube after exactly 90 seconds by adding $15 \mathrm{ml}$ of ice cold hypertonic restoring solution $\left(10.56 \mathrm{mM} \mathrm{Na} \mathrm{HPO}_{4}\right.$, $2.67 \mathrm{mM} \mathrm{NaH} \mathrm{PO}_{4}, 0.43 \mathrm{M} \mathrm{NaCl}, \mathrm{pH}$ 7.3). Leukocytes remaining in each tube were pelleted by centrifugation $(1000 \times \mathrm{g}$ for $5 \mathrm{~min}$ at $4^{\circ} \mathrm{C}$ ), supernatants aspirated and discarded, cells washed $\left(1000 \times \mathrm{g}\right.$ for $5 \mathrm{~min}$ at $\left.4^{\circ} \mathrm{C}\right)$ in $20 \mathrm{ml}$ of ice cold PBS, and the pellets dissolved in $8 \mathrm{ml}$ of cold TRIzol reagent (Life Technologies; Gaithersberg, MD) for $10 \mathrm{~min}$ at room temperature. Time that elapsed from blood sampling to cell lysis in TRIzol Reagent was less than 1.5 hours. Individual samples were pooled into one tube by collection time and stored in the TRIzol at $-80^{\circ} \mathrm{C}$ until RNA isolations were performed. RNA isolations were done according to the TRIzol manufacturer's instructions within a week of the $h+6$ sample collection. RNA concentrations and purities were determined on both pooled samples using spectrophotometry (260 and $280 \mathrm{~nm}$ readings; DU-650 spectrophotometer Beckman, Schaumburg, IL) and agarose gel electrophoresis (28 and $18 \mathrm{~S}$ rRNA band visualization following ethidium bromide staining). By these assessments, we obtained 30-40 $\mu \mathrm{g}$ of good quality leukocyte total RNA from each $24 \mathrm{ml}$ of blood collected.

\section{RNA labeling and hybridization to microarray} Leukocyte total RNAs $(5-20 \mu \mathrm{g})$ from blood samples collected on $\mathrm{d}-14$ and $\mathrm{h}+6$ were used as templates in 2 separate reverse transcription reactions (described in detail in our companion paper, Yao et al. 2001, this issue). Briefly, synthetic lambda Q gene RNA was spiked into each reaction (as a control for cDNA synthesis and as a positive hybridization control; Fig. 1b) and oligo $(\mathrm{dT})_{15}$ used as the primer for reverse transcription. First-strand cDNA from the $\mathrm{d}-14$ and $\mathrm{h}+6$ samples were differentially labeled with $\mathrm{Cy} 5$ and $\mathrm{Cy} 3$, respectively, using a commercial kit (Clontech, Inc., Palo Alto, CA), and the labeled cDNAs mixed and hybridized to the microarray (Fig. 2). Hybridization was performed for $\sim 18$ hours at $50^{\circ} \mathrm{C}$ in a sealed, humidified chamber (TeleChem International, Inc.; Sunnyvale, CA). Following hybridization, the microarray was washed 3 times, rinsed in 
$\mathrm{ddH}_{2} \mathrm{O}$, and dried by centrifugation in a cushioned $50 \mathrm{ml}$ conical centrifuge tube. The final microarray was immediately scanned (GeneTAC LS IV array scanner; Genomic Solutions), the image processed (GeneTAC LS software; Genomic Solutions, Inc.), and spots located (Fig. 1) and integrated with the spotting file of the robot. Finally, reports were created of total spot information and spot intensity ratio for subsequent data analyses.

\section{Data Analyses}

All spot data from this experiment were imported into a Microsoft Excel worksheet for analysis. Data were sorted by spot type and dye color so Cy3 and Cy5 profiles for the GAPDH dye/RNA loading and lambda Q gene controls could be assessed. First, GAPDH Cy3 intensity was regressed on GAPDH Cy5 intensity to determine if significant dye/RNA loading effects were present. We proceeded with analysis of the test spots without adjustments for GAPDH or lambda Q because individual BOTL cDNA were spotted on the microarray (in triplicate) within a single patch (Fig. 1b). Therefore, patch effects did not influence our ability to test our hypothesis that parturition alters leukocyte gene expressions.

For analysis of our test samples, spot data were resorted by clone number and dye to isolate the Cy3 and Cy5 labeled BOTL cDNAs. These were copied into a separate Excel worksheet, triplicate spot data plotted in a scatter graph, and $\mathrm{Cy} 3$ intensities regressed against $\mathrm{Cy} 5$ intensities to obtain a regression line. The sample mean $\mathrm{Cy} 5$ and $\mathrm{Cy} 3$ intensities for each of the triplicate spots were estimated and Student's 2tailed $t$-test was used to determine if expressions were significantly different on $\mathrm{d}-14$ versus $\mathrm{h}+6$. We also calculated Cy5:Cy3 ratios of the mean spot intensities to get an indication of the fold-changes in expressions of the BOTL genes from $\mathrm{d}-14$ to $\mathrm{h}+6$. These Cy5 and Cy3 sample means and $\mathrm{Cy} 5: \mathrm{Cy} 3$ ratios are the data sets presented in the Results section.

\section{Northern blot validation of differential gene expressions}

Clones containing inserts for 3 BOTL cDNAs identified on our microarray as true red in color (i.e., repressed in blood leukocytes at $\mathrm{h}+6$ relative to d-14) were selected as probes for Northern blot validation of differential gene expression. Blots were also probed with the GAPDH cDNA for normalizing purposes. Prior to radioactive labeling, the inserts of these 4 clones were PCR-amplified and visualized as single bright bands on a $1.0 \%$ agarose gel stained with ethidium bromide (not shown). Northern blot analysis was performed using total RNA isolated on $\mathrm{d}-14$ and $\mathrm{h}+6$ from leukocytes of one healthy periparturient Holstein cow (a different cow than for the microarray experiment) and a mix of leukocyte RNA from 4 healthy control cows in mid-gestation. Aliquots of $10 \mu \mathrm{g}$ of RNA from each sample were electrophoresed in a $15 \times 10 \mathrm{~cm} 1.2 \%$ denaturing agarose gel (Sub-Cell GT System; BioRad, Hercules, CA). Separated RNA was transferred from the gel to a nylon membrane (Hybond, Amersham Pharmacia Biotech, Buckinghamshire, UK) and baked for 2 hours at $80^{\circ} \mathrm{C}$. The blot was pre-hybridized for 2 hours at $68^{\circ} \mathrm{C}$ in $10 \mathrm{ml}$ of PerfectHyb Plus hybridization solution (Sigma; St. Louis, MO) containing $400 \mu \mathrm{g} / \mathrm{ml}$ of herring sperm DNA. Hybridization was carried out for $16 \mathrm{~h}$ at $68^{\circ} \mathrm{C}$ in the same solution using the cDNA probes labeled with ${ }^{32} \mathrm{P}$ (NEN Life Science Products, Inc.; Boston, MA) by the random prime method (Feinberg \& Vogelstein 1983). After hybridizations, the membranes were washed once at room temperature with $2 \mathrm{x}$ SSC, $0.1 \%$ SDS for $5 \mathrm{~min}$ and 2 times with $0.5 \mathrm{x}$ $\mathrm{SSC}, 0.1 \% \mathrm{SDS}$ at $68^{\circ} \mathrm{C}$ for $20 \mathrm{~min}$ prior to exposure to BioMax MS film (Fisher Scientific, Pittsburgh, PA) for 19 hours at $-80^{\circ} \mathrm{C}$ with an 
(a)

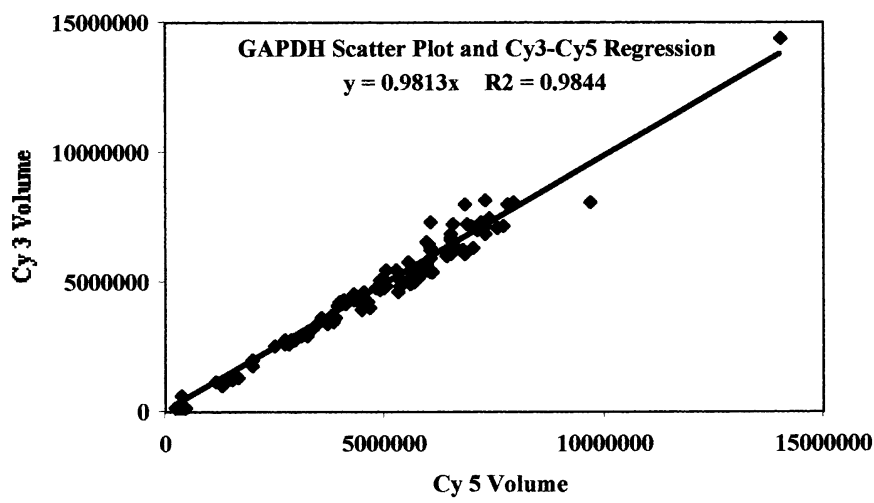

(b)

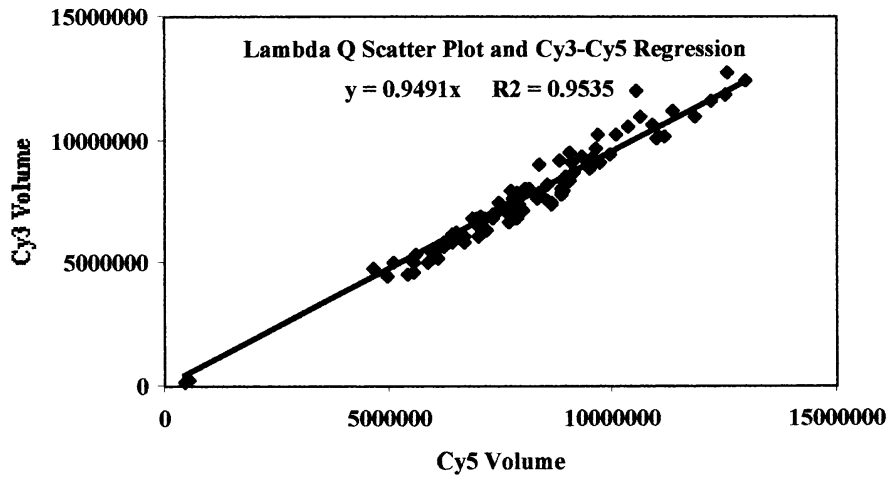

Figure 3. Regression analyses of the GAPDH control spots (a) and the lambda Q gene control spots (b) on the cDNA microarray shown in Fig. 1a. In these analyses, Cy3 spot intensities (volumes) were regressed on Cy5 spot intensities to determine if the GAPDH and lambda Q spots were yellow (i.e., lying close to the regression line and indicating no dye/RNA loading effects) and well clustered (i.e., showing no patch variation).

intensifying screen (Fisher Scientific, Pittsburgh, PA). Expressions of the 3 test transcripts and the GAPDH transcript were estimated from each band using a scanning densitometer (GS710 Calibrated Imaging Densitometer and Multi-Analyst Software; BioRad, Hercules, CA; data not shown) and expression data for the test transcripts recorded as a ratio to GAPDH expression.

\section{Results}

As shown in the scatter plot in Fig. 3a, the Cy3 and Cy5 spots for GAPDH lay in a relatively tight cluster and very close to the regression line, which had a slope of $\sim 1.0$. Therefore, except for 5 or 6 outliers (expected for this scale of gene expression analysis), we observed no particular trends in dye or RNA loading effects in this experiment (i.e., the $\mathrm{Cy} 3$ intensity was equal to the Cy5 intensity for GAPDH). One 


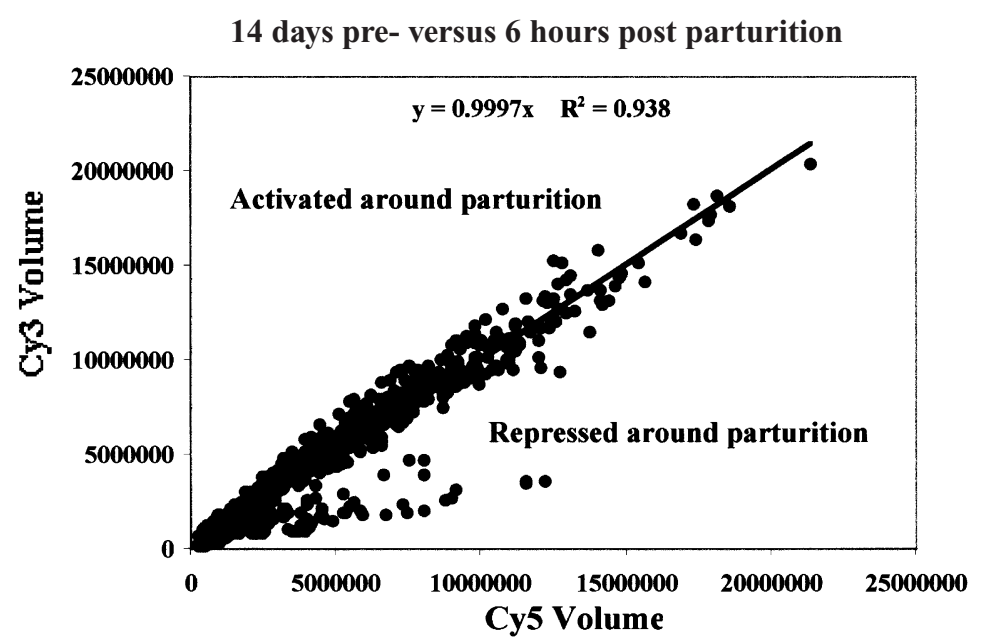

Figure 4. Regression analysis of the BOTL test spots on the cDNA microarray shown in Fig. 1. In this analyses, Cy3 spot intensities (volumes) were regressed on Cy5 spot intensities to determine if the leukocytes collected 6 hours postpartum $(\mathrm{h}+6)$ had different gene expressions than leukocytes collected 14 days prepartum $(\mathrm{d}-14)$. This analysis showed that most leukocyte genes represented on our microarray were equally expressed on $\mathrm{d}-14$ and $\mathrm{h}+6$ because the majority of the spots on the scatter plot clung tightly to the regression line, which had a slope very close to 1.0. However, this analysis revealed 54 overlapping spots in the Cy5 area of the plot, which represented triplicate spots for 18 unique BOTL cDNAs that were repressed 6 hours after parturition.

point of note, however, was that the GAPDH spots had a tendency to form a narrow tail into the low intensity region of the plot (Fig. 3a). We took this to mean that not all of the GAPDH spots yielded the same yellow intensity due to patch-specific effects. Indeed, a similar analysis of the lambda $Q$ gene spots ( 2 per patch for a total of 96 spots) showed evidence of patch effects because there was a stretched line of Cy3Cy5 data points instead of a defined cluster of points (Fig. 3b). However, the slope of this regression line was also close to 1.0 with tight hovering of the lambda Q Cy3 and Cy5 spots to the regression line. As for the GAPDH analysis, this indicated no dye or RNA loading effects.

As shown in Fig. 4, the regression of $\mathrm{Cy} 3$ and Cy5 had a slope of 0.9997 with most data points clustering tightly to the line $\left(\mathrm{R}^{2}=0.938\right)$. This indicated that most of the test spots had various intensities of yellow fluorescence, the genes represented by the cDNAs on those spots being expressed equally at $\mathrm{d}-14$ and $\mathrm{h}+6$. No leukocyte genes appeared to be activated at $\mathrm{h}+6$ because no spots were obviously more green (Cy3) than red (Cy5) (Fig. 4). However, a small cluster of genes did fall into the $\mathrm{Cy} 5$ region of the plot (Fig. 4) and appeared obviously red on the processed microarray file (Fig. 1), showing that these genes were repressed at $\mathrm{h}+6$ relative to $\mathrm{d}-14$.

Data obviously falling away from the regression line into the Cy5 region of the BOTL scatter plot (Fig. 4) represented triplicate spots for 18 BOTL cDNAs. These spots lay clearly in the Cy5 region of the scatter plot indicating that the 18 genes represented by them were repressed 6 hours following parturition $(\mathrm{h}+6)$ compared to 14 days prepartum $(\mathrm{d}-14)$. Therefore, we have 
identified 18 leukocyte genes that are repressed during parturition.

The wide distribution of the clustered Cy5 spots in the scatter plot in Fig. 4 indicated wide variation in red dye intensities amongst these 18 BOTL cDNAs. These could be seen on the actual microarray as spots that ranged in color from true red to reddish-brown (Fig. 1). Differences in Cy5 intensity of these spots could mean that these 18 genes have different expression levels in bovine blood leukocytes. However, given the patch-to-patch variation in the Cy3-Cy5 (yellow) spot intensities of the lambda Q gene (Figs. 1a and 3b), differences in the Cy5 intensities of this cluster of red BOTL spots may simply reflect the patch variation on our microarray. Establishing the relative contributions of gene expression versus patch variation in this study would require additional Northern blot and microarray analyses of these 18 BOTL cDNAs. However, source of variation in Cy5 intensity from cDNA to cDNA was not important in the current study because our goal was to test differences in expression between the $\mathrm{d}-14$ and $\mathrm{h}+6$ samples within individual cDNAs. This goal was reflected in the fact that we spotted individual cDNAs only within a patch and not across patches on the microarray (Fig. 1; refer to Materials and methods section). Nonetheless, for simplification of data presentation we have plotted the sample means ( \pm SEM) for expression differences in our 18 BOTL cDNAs by relative Cy5 intensity level (i.e., expression on $\mathrm{d}-14$ ). Six of these cDNAs fell in the low intensity region (Cy5 intensity range $\sim 50,000$ to 400,000 ; Fig. 5), 8 in the medium intensity region ( $\mathrm{Cy} 5$ intensity range $\sim 100,000$ to 700,00 ; Fig. 6 ), and 4 in the high intensity region (Cy5 intensity range $\sim 200,000$ to $12,000,000$; Fig. 7).

Sample means in Fig. 5 show that leukocyte genes represented by our BOTL clones 8_F09, 6XG09R, 4XD09R, and 8_B07 were signifi- cantly $(P \leq 0.04)$ repressed on $\mathrm{h}+6$ compared to $\mathrm{d}-14$ relative to parturition. These genes were $\sim 1.5$-fold to 4-fold higher in expression in the prepartum sample than the postpartum sample (Fig. 8). Leukocyte genes represented by BOTL clones 9_F09 $(P=0.06)$ and 5XC11R $(P=$ 0.13 ) tended to be lower at $\mathrm{h}+6$ compared to $\mathrm{d}$ -14 (Fig. 5). These genes both had $\sim 1.5$-fold higher expression prepartum than postpartum (Fig. 8). BLASTN results in Table 1 showed that the BOTL cDNA sequences for the 6 repressed genes in Fig. 5 were either unknown (9_G07, 4XD09R) or had high homology with molecules involved in DNA binding and transcription (6XG09R, 8-B07) and signal transduction (8_F09). Sample means in Fig. 6 show that leukocyte genes represented by our BOTL clones 12_B09, 12_B06, 8_B05, 13_B06, 6XC10R, 10-A07, and 3XA10R were also significantly $(P \leq 0.04)$ repressed on $\mathrm{h}+6$ compared to $\mathrm{d}-14$. These genes were expressed $\sim 1.2$-fold to 3.5 -fold higher in the prepartum sample than the postpartum sample (Fig. 8). The leukocyte gene represented by BOTL clone 4XD08R tended $(\mathrm{P}=0.06)$ to be lower at $\mathrm{h}+6$ compared to $d-14$ (Fig. 6). This gene had $\sim 2.3$ fold higher expression prepartum than postpartum (Fig. 8). BLASTN results in Table 1 showed that the BOTL cDNA sequences for the 8 repressed genes in Fig. 6 were either unknown (8_B05, 10_A07) or had high homology with a variety of molecules involved in hormone binding (12_B09), cell growth (12_B06), leukocyte extravasation (6XC10R), and cell signaling (4XD08R, 3XA10R). Finally, sample means in Fig. 7 show that leukocyte gene expression represented by our BOTL clones 6XH09R, 3XD01R, 8_F08, and 2XH12R were highly significantly $(P \leq 0.004)$ repressed at $\mathrm{h}+6$ compared to $d-14$. These genes were $\sim 1.7$-fold to 4-fold higher in expression in the prepartum sample than the postpartum sample (Fig. 8). BLASTN results in Table 1 showed that the 


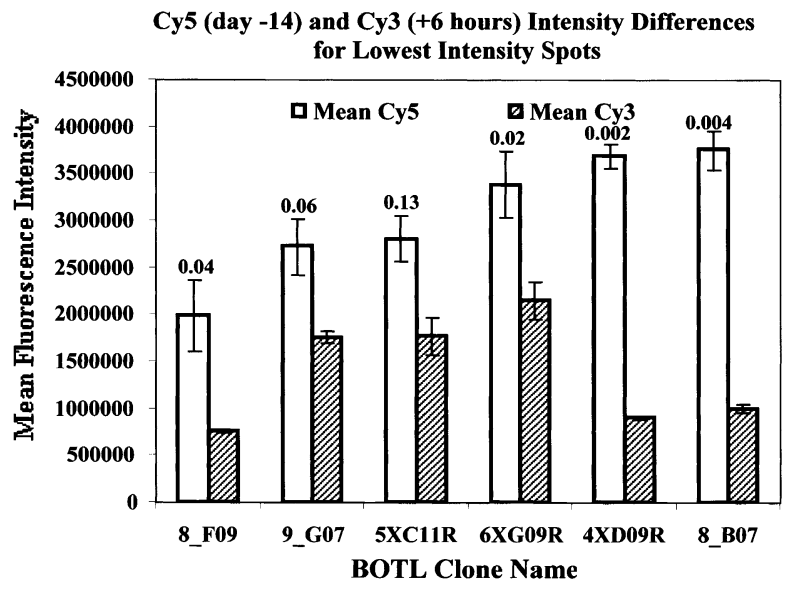

Figure 5. Sample mean fluorescence intensities ( \pm SEM) of triplicate spots for 6 leukocyte clones identified by cDNA microarray analysis to be repressed at 6 hours postpartum $(\mathrm{h}+6$; striped bars) compared to 14 days prepartum (d-14; open bars). Data are for BOTL clones showing lowest Cy5 (red; $d-14)$ intensities on the microarray in Fig. 1 and falling in the cluster of Cy5 spots in Fig. 4. High Cy5 intensity relative to Cy3 intensity in each cluster of 2 bars shows that genes represented by these 6 BOTL clones were significantly repressed following parturition (numbers above the open bar in each cluster are the $P$ values from Student's 2-tailed t-tests).

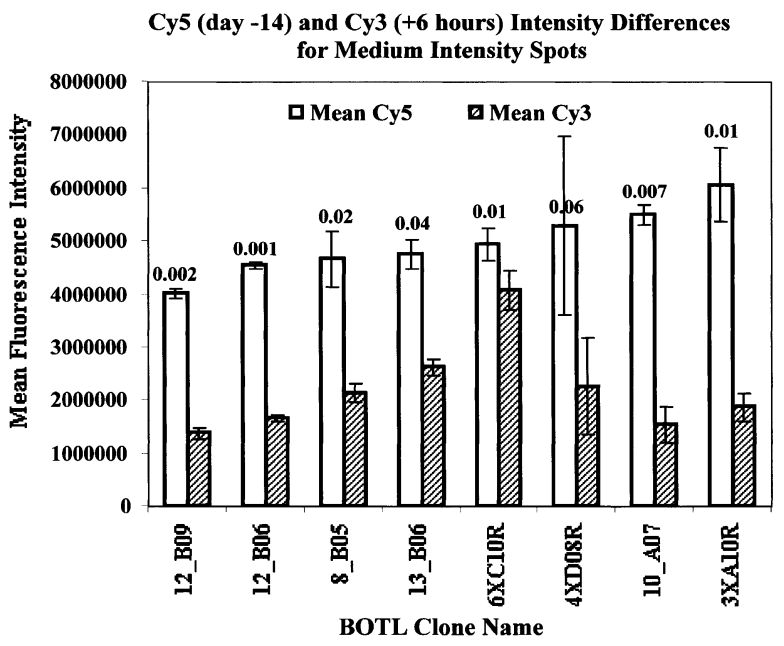

Figure 6. Sample mean fluorescence intensities ( \pm SEM) of triplicate spots for 8 leukocyte clones identified by cDNA microarray analysis to be repressed at 6 hours postpartum $(\mathrm{h}+6$; striped bars) compared to 14 days prepartum ( $d-14$; open bars). Data are for BOTL clones showing medium Cy5 (red; d -14) intensities on the microarray in Fig. 1 and falling in the cluster of Cy5 spots in Fig. 4. High Cy5 intensity relative to Cy3 intensity in each cluster of 2 bars shows that genes represented by these 6 BOTL clones were significantly repressed following parturition (numbers above the open bar in each cluster are the $P$ values from Student's 2-tailed t-tests). 


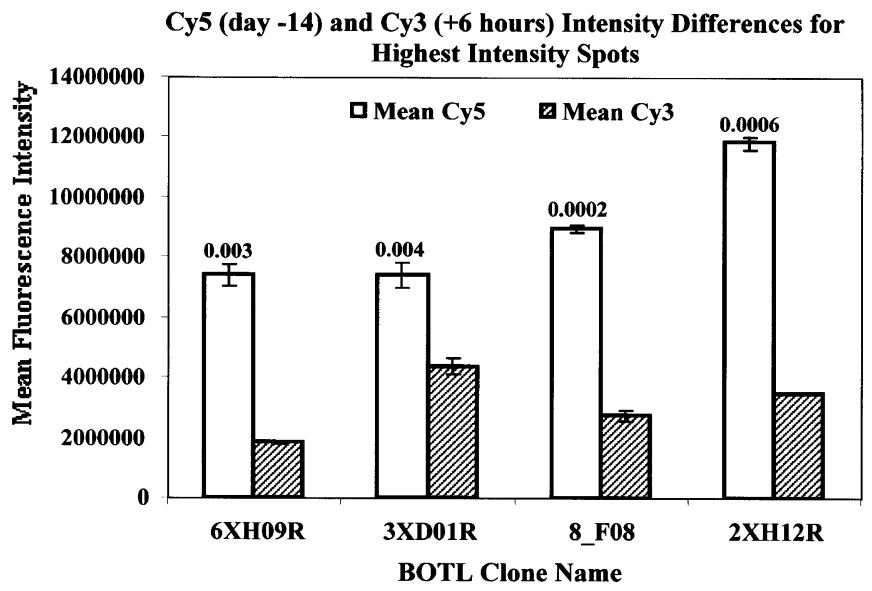

Figure 7. Sample mean fluorescence intensities ( \pm SEM) of triplicate spots for 4 leukocyte clones identified by cDNA microarray analysis to be repressed at 6 hours postpartum ( $h+6$; striped bars) compared to 14 days prepartum (d-14; open bars). Data are for BOTL clones showing high Cy5 (red; $d-14$ ) intensities on the microarray in Fig. 1 and falling in the cluster of $\mathrm{Cy} 5$ spots in Fig. 4. High Cy5 intensity relative to Cy3 intensity in each cluster of 2 bars shows that genes represented by these 6 BOTL clones were significantly repressed following parturition (numbers above the open bar in each cluster are the $P$ values from Student's 2-tailed t-tests).

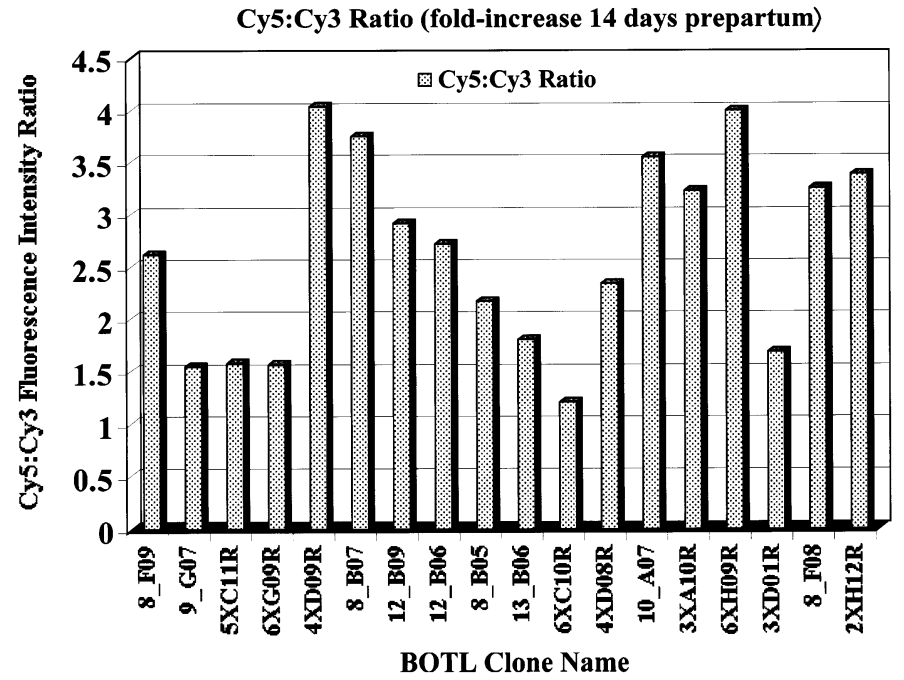

Figure 8. Mean Cy5:Cy3 intensity ratios for 18 leukocyte genes identified by cDNA microarray analysis to be repressed at 6 hours postpartum compared to 14 days prepartum. Data are for 18 BOTL clones showing as red spots on the microarray in Fig. 1 and falling in the cluster of Cy5 spots in Fig. 4. Data in this figure showed that the 18 leukocyte genes represented by these BOTL clones had between 1.2-fold and 4-fold higher expression levels 14 days before parturition than 6 hours after parturition. 
Table 1. Results of BLASTN analysis of 18 BOTL sequences shown by cDNA microarray analysis to be repressed by parturition.

\begin{tabular}{|c|c|c|c|c|}
\hline $\begin{array}{l}\text { BOTL } \\
\text { Clone } \\
\text { Name }\end{array}$ & $\begin{array}{c}P \text {-value }{ }^{1)} \\
(\mathrm{d}-14 \text { vs h }+6)\end{array}$ & $\begin{array}{c}\text { BLASTN results } \\
\text { (putative gene identification) }\end{array}$ & E-value ${ }^{2)}$ & $\begin{array}{l}\text { TIGR Cluster } \\
\text { (TC\#) or } \\
\text { GenBank \#3) }\end{array}$ \\
\hline \multicolumn{5}{|c|}{ Observed by microarray analysis and confirmed by Northern blot hybridization: } \\
\hline 6XGO9R & 0.02 & Kruppel-like factor mRNA & $10^{-37.69}$ & TC71106 \\
\hline 8_F09 & 0.04 & $\begin{array}{c}\text { Mitogen activated protein kinase } \\
\text { kinase kinase } 10 \text { (MAP3K10) } \\
\text { mRNA }\end{array}$ & $10-57.15$ & $\begin{array}{c}4505262 \\
11425967\end{array}$ \\
\hline 13_B06 & 0.04 & Unknown & - & - \\
\hline
\end{tabular}

Observed by microarray analysis:

\begin{tabular}{|c|c|c|c|c|}
\hline 9_G07 & 0.06 & Unknown & - & - \\
\hline $5 \mathrm{XC} 11 \mathrm{R}$ & 0.13 & $\begin{array}{l}\text { Bos taurus lysosomal alpha- } \\
\text { mannosidase (ManB) gene }\end{array}$ & $10^{-9}$ & TC74217 \\
\hline 4XD09R & 0.002 & Unknown & - & - \\
\hline 8_B07 & 0.004 & $\begin{array}{c}\text { Basic leucine zipper transcription } \\
\text { factor-like mRNA }\end{array}$ & $10^{-116}$ & TC68695 \\
\hline 12_B09 & 0.002 & Bovine beta-globulin gene & $10^{-36.3}$ & TC61928 \\
\hline 12_B06 & 0.001 & $\begin{array}{l}\text { Bovine ornithine decarboxylase } \\
\text { (ODC) gene }\end{array}$ & $10^{-19.52}$ & TC69145 \\
\hline 8_B05 & 0.02 & Unknown & - & - \\
\hline $6 \mathrm{XC10R}$ & 0.01 & $\begin{array}{l}\text { Mus musculus plectin isoform plec } \\
\text { 0a, 1c (Plec 1) mRNA }\end{array}$ & $10^{-28}$ & 6578732 \\
\hline 4XD08R & 0.06 & $\begin{array}{l}\text { Bos taurus matrix acidic } \\
\text { phosphoprotein mRNA }\end{array}$ & $10^{-10}$ & TC76407 \\
\hline 10_A07 & 0.007 & Unknown & - & - \\
\hline $3 \mathrm{XA10R}$ & 0.01 & $\begin{array}{l}\text { Diphosphoinositol polyphosphate } \\
\text { phosphohydrolase }\end{array}$ & $10^{-32.15}$ & TC69522 \\
\hline 6XH09R & 0.003 & $\begin{array}{c}\text { Long chain fatty acid CoA ligase } 4 \\
\text { (acyl CoA synthetase } 4)\end{array}$ & $10^{-126}$ & TC72044 \\
\hline 3XD01R & 0.004 & $\begin{array}{l}\text { Diphosphoinositol polyphosphate } \\
\text { phosphohydrolase mRNA }\end{array}$ & $10-31.52$ & TC69522 \\
\hline 8_F08 & 0.0002 & Unknown & - & - \\
\hline 2XH12R & 0.0006 & $\begin{array}{c}\text { Bovine mRNA for MHC class II } \\
\text { DM } \beta \text {-chain }\end{array}$ & $10^{-41.69}$ & TC6553 \\
\hline
\end{tabular}

1) $P$-value from the t-tests comparing sample time dye intensities of BOTL spots on the cDNA microarray,

2) expectation values (E-value) from the BLAST search, and

3) TIGR cluster number or GenBank number to which the BOTL sequence had homology. 


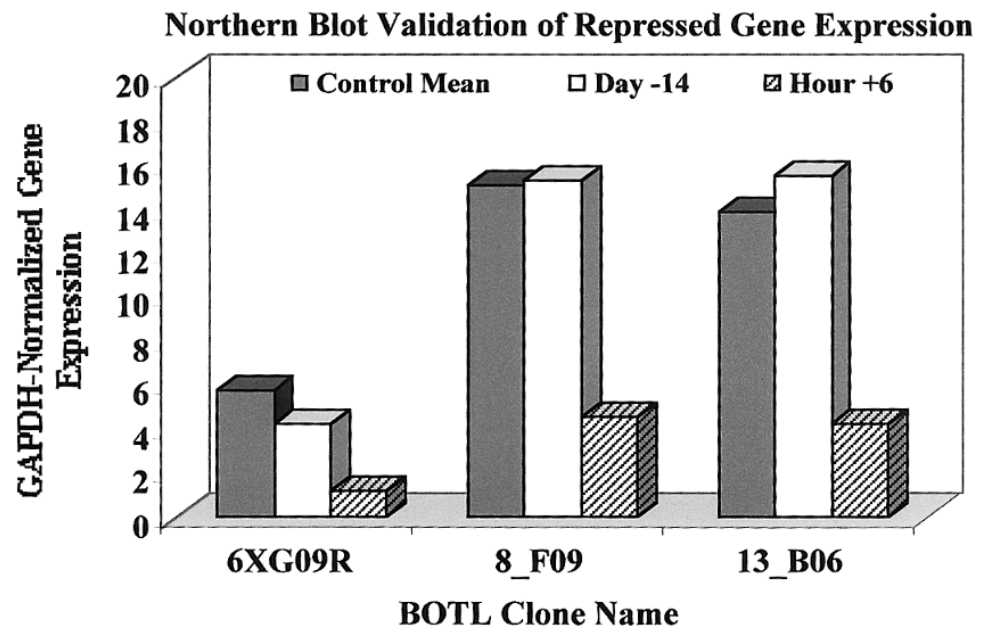

Figure 9. Northern blot validation of repressed gene expression in leukocytes from parturient dairy cows. Three BOTL clones that appeared to have triplicate spots of true red the cDNA microarray (see Fig. $1 \mathrm{~b}$ for an example) were selected for use as cDNA probes on Northern blot analyses of leukocyte RNA from 4 mid-lactation control cows (RNA was pooled; gray bars) and from one periparturient cow collected 14 days prepartum (d -14 ; open bars) and 6 hours postpartum $(\mathrm{h}+6$; striped bars). Band intensities for the 3 test transcripts were normalized against band intensities for GAPDH. These data confirm dye intensity results in Fig. 5 and 6, dye ratio results in Fig. 8, and visual microarray results in Fig. 1, that genes represented by BOTL clones 6XG09R, 8_F09, and 13_B06 are repressed right after parturition.

BOTL cDNA sequences for the 4 repressed genes in Fig. 7 were either unknown (8_F09) or had high homology with a variety of molecules involved in fatty acid synthesis (6XH09R), cell signaling (3XD01R), and antigen presentation (2XH12R). Northern blot analysis of 6XG09R, 8_F09, and 13_B06 confirmed that these 3 leukocyte genes were significantly repressed following parturition (Fig. 9). Therefore, results of our study support our hypothesis by showing that parturition negatively affects gene expression profiles of bovine blood leukocytes.

\section{Discussion}

We know from extensive literature on the subject that most functions of bovine leukocytes are dramatically altered by parturition and that significant genetic variation exists in these dys- functional leukocyte traits (see Introduction). These leukocyte dysfunctions probably underlie the heightened mastitis susceptibility of periparturient cows, but the genes involved in this complex disease etiology are virtually unknown. Understanding the molecular bases for leukocyte dysfunctions around parturition will open the doors to a plethora of targeted studies aimed at discovery of multiple management tools that truly improve mammary immunity and mastitis resistance in periparturient cows. Examples include the elucidation of biologically relevant molecular genetic markers for genetic selection against periparturient mastitis susceptibility, nutritional and other management manipulations to influence leukocyte gene expression in favor of improved mammary immune defenses, and development of new non- 
antibiotic pharmaceuticals that protect leukocytes from the suppressing effects of parturition. Getting to the bottom of the overwhelming task of such large-scale gene identification has been made simple by new cDNA microarray technology that allows us to study expression changes in hundreds of cellular genes at one time (DeBouck \& Goodfellow 1999, Khan, et al. 1999, Kurian et al. 1999, Ramsay 1998, Schena et al. 1998). We took this holistic approach to begin studying effects of parturition on leukocyte gene expression profiles for a Holstein cow approaching and going through parturition.

In this study, regression analysis of all test BOTL spots showed that, as expected, the majority of leukocyte genes represented on our microarray were equally expressed 14 days before and 6 hours after parturition (i.e., were yellow; Fig. 1 and 4). However, a cluster of spots falling in the Cy5 region of Fig. 4 showed that 18 leukocyte genes were repressed 6 hours after parturition, 15 of them significantly so (Figs. 5, 6 , and 7) and 12 of them at a level of 2-fold or higher (Fig. 8). Six of the repressed genes did not consistently hit DNA sequence targets in the TIGR or GenBank databases and are thus currently unknown (Table 1). Of the remaining 12 BOTL genes that did have significant DNA sequence homology with known genes in the data bases, only one could be considered a "classical" immune response gene (2XH12R, the $\beta$-chain of MHC class II; Table 1). The other 11 leukocyte genes we detected as being repressed by parturition had high DNA sequence homology with genes known to be important in normal cell growth, metabolism, and responsiveness to the blood environment (Table 1). Two of these genes are involved in gene transcription itself (6XG09R, 8_B07; Table 1).

Therefore, we conclude from the microarray data presented in this study that parturition influences the expression of multiple leukocyte genes required for normal functioning of these cells. Repressed expression of these genes could easily explain the dysfunctional capacities of leukocytes from periparturient cows reported over the past 3 decades by multiple laboratories (Hill et al. 1979, Guidry et al. 1976, Hill 1981, Oliver \& Sordillo 1988, Nagahata et al. 1988, Kehrli et al. 1989a,b, Cai et al. 1994, Detilleux et al. 1994, 1995a,b, Sordillo et al. 1997, Lee \& Kehrli 1998, Mallard et al. 1998, Van Kampen et al. 1999, Waller 2000). However, we have not yet determined which population of leukocytes are affected or what factors of parturition cause the repression of our 18 leukocyte genes. Preliminary studies from our group implicate neutrophils as the main leukocyte targets of parturition-induced gene expression changes (Madsen et al. 2000, Weber et al. 2001). This is important because neutrophils are the main line of immunological defense against mastitis-causing bacteria in dairy cows (Paape et al. 1979). However, additional studies will be required to determine if the 18 repressed genes identified in the current study were contributed from the neutrophil population of circulating leukocytes and if expression of any of these genes is linked with mastitis susceptibility around parturition.

\section{Conclusions}

The microarray experiment performed in this study has putatively identified 18 genes normally expressed in blood leukocytes 14 days before parturition but dramatically repressed in leukocytes shortly after parturition. While some of these leukocyte genes currently have no known name or function, many of them showed high DNA sequence homology to genes required for normal cell functions. Because many of the genes identified in this study allow cells to respond to biochemical signals in the blood environment, it will be interesting to determine in future studies if our observed 
changes in gene expression are related to fluctuating hormone concentrations and nutrient status of periparturient cows. We hope that the new knowledge generated about gene expression changes in leukocytes of parturient dairy cows will ultimately be useful for the development of novel management strategies to combat immunosuppression and mastitis susceptibility during this tricky stage in a cow's lactation cycle. Major future goals of our group will be to determine which leukocyte genes participate in the regulation of mammary immunity and study them as potential candidate markers for genetic selection to improve mastitis resistance in disease susceptible periparturient cows. As with so many colleagues before us, it is our belief that a genetic approach to improved leukocyte functions will help counteract any negative effects that selection for high milk yield has had on mammary immunity.

\section{Acknowledgements}

Warm thanks are extended to Dr. P.S.D. Weber, Dr. A. Chaiyotwittayakun, Ms. J.B. Wells, and Ms. R.A. Darch for their assistance with blood collections and RNA isolations. This study was supported through generous funding by the Department of Animal Science at Michigan State University, the Michigan Agricultural Experiment Station, Michigan State University's Office for the Vice President of Research and Graduate Studies, and the Michigan Animal Industry Coalition.

\section{References}

Almlid T: Indirect selection of bulls for improved resistance to diseases in dairy cattle. Livestock Prod. Sci. 1981, 8, 321-330.

Burton JL: Immunogenomics and the periparturient dairy cow: letting leukocytes tell us their own story about disease susceptibility. American Dairy Science Association's Symposium on Genetics of Disease Resistance (in association with the International Animal Agriculture and Food Science Conference). Indianapolis, July 24-28, 2001. J. Dairy Sci. 2001, 84, (Suppl. 1): 56-57 (abstract 236).

Burton JL, Perkins KH, Chaiyotwittayakun A, Ersk- ine RJ: How Do Nutrients Affect the Immune System? Proceedings of the Tri-State Dairy Nutrition Conference. April 17-19, 2000. Fort Wayne, 2000. IN. Pp. 1-25.

Cai TQ, Weston PG, Lund LA, Brodie B, McKenna $D J$, Wagner WC: Association between neutrophil functions and periparturient disorders in cows. Am. J. Vet. Res. 1994, 55, 934-943.

Cullor, JS: The role of vaccines in the prevention and moderation of clinical mastitis. Proc. 30th Ann. Mtg. Natl. Mast. Council. 1991. Pp. 68-75.

DeBouck C, Goodfellow PN: DNA microarrays in drug discovery and development. Nature Genetics Supplement 1999, 21, 48-50.

Detilleux JC, Koehler KJ, Freeman AE, Kehrli Jr ME, Kelley $\mathrm{DH}$ : Immunological parameters of periparturient Holstein cattle: genetic variation. J. Dairy Sci. 1994, 77, 2640-2650.

Detilleux, J. C., M.E. Kehrli, Jr., A.E. Freeman, L.K. Fox, and D.H. Kelley. 1995a. Mastitis of periparturient Holstein cattle: a phenotypic and genetic study. J. Dairy Sci. 78:2285-2293.

Detilleux JC, Kehrli Jr ME, Stabel JR, Freeman AE, Kelley $D H$ : Study of immunological dysfunction in periparturient Holstein cattle selected for high and average milk production. Vet. Immunol. Immunopathol. 1995b, 44, 251-267.

Dietz AB, Cohen ND, Timms L, Kehrli ME Jr: Bovine lymphocyte antigen class II alleles as risk factors for high somatic cell counts in milk of lactating dairy cows. J. Dairy Sci. 1997, 80, 406-412

Eberhart RJ: Coliform mastitis. Vet. Clin. North Am. Large Anim. Pract. 1994, 6, 287-300.

Eberhart RJ: Management of dry cows to reduce mastitis. J. Dairy Sci. 1986, 69, 1721-1732.

Erskine RJ, Bartlett PC: Assessing the success of clinical mastitis treatment: What are production medicine goals? Agri-Practice 1995, 16, 6.

Erskine RJ, Eberhart RJ, Hutchinson LJ, Spencer SB, Campbell $M A$ : Incidence and types of clinical mastitis in dairy herds with high and low somatic cell counts. J. Am. Vet. Med. Assoc. 1988, 192, 761-765.

Gonzalez RN, Jasper DE, Farver TB, Bushnell RB, Franti $C E$ : Prevalence of udder infections and mastitis in 50 California dairy herds. J. Am. Vet. Med. Assoc. 1988, 193, 323-328.

Gonzalez RN, Jasper DE, Kronlund NC, Farver TB, Cullor JS, ushnell RB, Dellinger JD: Clinical mastitis in two California dairy herds participating in contagious mastitis control programs. J. Dairy Sci. 1990, 73, 648-660. 
Gonzalez RN, Cullor JS, Jasper DE, Farver TB, Bushnell RB, Oliver $M N$ : Prevention of clinical coliform mastitis in dairy cows by a mutant Escherichia coli vaccine. Can. J. Vet. Res., 1989, 53, 301-305.

Guidry AJ, Paape MJ, Pearson RE: Effects of parturition and lactation on blood and milk cell concentrations, corticosteroids and neutrophil phagocytosis in the cow. Am. J. Vet. Res. 1976, 37, 1195-1200.

Hogan JS, Smith KL, Hoblet KH, Schoenberger PS, Todhunter DA, Hueston WD, Pritchard DE, Bowman GL, Heider LE, Brockett BL: Field survey of clinical mastitis in low somatic cell count herds. J. Dairy Sci. 1989, 72, 1547-1556.

Hogan JS, Smith KL, Todhunter DA, Schoenberger $P S$ : Field trial to determine efficacy of an Escherichia coli J5 mastitis vaccine. J. Dairy Sci. 1992a, 75, 78-84.

Hogan JS, Weiss WP, Todhunter DA, Smith KL, Schoenberger PS: Efficacy of an Escherichia coli J5 mastitis vaccine in an experimental challenge trial. J. Dairy Sci. 1992b, 75, 415-422.

Feinberg AP, Vogelstein B: A technique for radiolabeling DNA restriction endonuclease fragments to high specific activity. Anal. Biochem., 1983, 132, 6-13.

Freeman AE, Lindberg GL: Challenges to dairy cattle management: genetic considerations. J. Dairy Sci. 1993, 76, 3143-3159.

Funk DA: Optimal genetic improvement for the high producing herd. J. Dairy Sci. 1993, 76, 32783286 .

Hill $A W$ : Factors influencing the outcome of Escherichia coli mastitis in the dairy cow. Res. Vet. Sci. 1981, 31, 107-112.

Hill $A W$, Shears AL, Hibbitt KG: The pathogenesis of experimental Escherichia coli mastitis in newly calved dairy cows. Res. Vet. Sci. 1979, 26, $97-$ 101.

Hoblet KH, Schnitkey GD, Arbaugh D, Hogan JS, Smith KL, Schoenberger PS, Todhunter DA, Hueston WD, Pritchard DE, Bowman GL, et al.: Costs associated with selected preventive practices and with episodes of clinical mastitis in nine herds with low somatic cell counts. J. Am. Vet. Med. Assoc., 1991, 199, 190-196.

Jensen PT, Madsen P, Jensen NE: Serum immunoglobulin levels in cattle: genetic variation and relation to disease. Proc. 32 ${ }^{\text {nd }}$ Ann. Mtg. EAAP. Zagreb. Aug. 31-Sept. 3., 1981.

Khan J, Bittner ML, Chen Y, Meltzer PS, Trent JM:
DNA microarray technology: the anticipated impact on the study of human disease. Biochimica et Biophysica Acta 1999, 1423, M17-M28.

Kehrli ME Jr, Nonnecke BJ, Roth JA: Alterations in bovine neutrophil function during the periparturient period. Am. J. Vet. Res. 1989a, 50, 207-214.

Kehrli ME Jr, Nonnecke BJ, Roth JA: Alterations in bovine lymphocyte function during the peripartum period. Am. J. Vet. Res. 1989, 50, 215.

Kelm SC, Detilleux JC, Freeman AE, Kehrli ME Jr, Dietz AB, Fox LK, Butler JE, Kasckovics I, Kelley $\mathrm{DH}$ : Genetic association between parameters of inmate immunity and measures of mastitis in periparturient Holstein cattle. J. Dairy Sci. 1997, 80, 1767-1775.

Kurian KM, Watson CJ, Wyllie AH: DNA chip technology. J. Pathol. 1999, 187, 267-271.

Lee E-K, Kehrli ME Jr: Expression of adhesion molecules on neutrophils of periparturient cows and neonatal calves. Am. J. Vet. Res. 1998, 59, 37-43.

Legates JE, Grinnells CD: Genetic relationships in resistance to mastitis in dairy cattle. J. Dairy Sci. 1952, 35, 829-833.

Lewin HA: Disease resistance and immune response genes in cattle: strategies for their detection and evidence of their existence. J. Dairy Sci. 1989, 72, 1334-48

Lie $O$ : Genetic variations in the antibody response in young bulls. Acta Vet. Scand. 1977, 18, 572-574.

Lie $O$ : Genetic analysis of some immunological traits in young bulls. Acta Vet. Scand. 1979, 20, 372386.

Lie $O$, Solbu $H$ : A working model for the evaluation of different immunological traits as indicators of resistance to infection in dairy cattle. Acta Vet. Scand. 1981, 22, 238-245.

Lie O, Solbu H, Spooner RL, Larsen HJ, Syed M: General design of a study on markers of disease resistance in cattle. Proc. $2^{\text {nd }}$ World Congress on the Genetics of Livestock Production. Madrid, Oct. 4-8, 1982. 378-384.

Lie $O$, Solbu H, Syed M: A genetic association between bovine serum and colostrum lysozyme levels. Anim. Genet. 1986, 17, 39-45.

Lindé B: Possibilities to include disease resistance in dairy cattle breeding. Proc. $2^{\text {nd }}$ World Congress on the Genetics of Livestock Production. Madrid. Oct. 4-8, 1982. 336-341.

Lindström,UB, Syväjärvi J: Use of field records in breeding for mastitis resistance in dairy cattle, Livestovk Prod. Sci. 1978, 5, 29-44. 
Madsen SA, Weber PSD, Burton JL: Altered leukocyte gene expression in parturient dairy cows. American Association of Veterinary Immunologists Online Newsletter 2000 (Jan., 2001).

Mallard BA, Dekkers JC, Ireland MJ, Leslie KE, Sharif S, Vankampen CL, Wagter L, Wilkie BN: Alteration in immune responsiveness during the peripartum period and its ramification on dairy cow and calf health. J. Dairy Sci. 1998, 81, 585595.

Mazengera KE, Kennedy BW, Burnside EB, Wilkie $B N$, Burton JH: Genetic parameters of bovine serum immunoglobulins. J Dairy Sci. 1985, 68, 2309-2314.

McDnaiel BT: Progeny testing for disease resistance and stayability. IDF/EAAP Symposium: Progeny testing methods in dairy cattle. Prague. Sept. 1416,1984 .

Mejdell CM, Lie O, Solbu H, Arnet EF, Spooner RL: Association of major histocompatibility complex antigens (BoLA-A) with AI bull progeny test results for mastitis, ketosis and fertility in Norwegian cattle. Anim. Genet. 1994, 25, 99-104.

Miller RH, Paape MJ, Filep R, Link S: Flow cytometric analysis of neutrophils in cow's milk. Am. J. Vet. Res. 1993, 12, 1975-1979.

Nagahata HS, Makino H, Takahashi H, Noda H: Assessment of neutrophil function in the dairy cow during the perinatal period. J. Vet. Med. 1988, 35 , 747-751.

National Mastitis Council: Current Concepts of Bovine Mastitis, Fourth Edition. The National Mastitis Council, Madison, 1996, WI 53704.

Oliver SP, Sordillo LM: Udder health in the periparturient period. J. Dairy Sci. 1988, 71, 2584-2606.

Paape MJ, Wergin WP, Guidry AJ, Pearson RE: Leukocytes-second line of defense against invading mastitis pathogens. J. Dairy Sci. 1979, 62, 135-153.

Preisler MT, Weber PSD, Tempelman RJ, Erskine RJ, Hunt H, Burton JL: Glucocorticoid receptor down-regulation in neutrophils of periparturient cows. Am. J. Vet. Res. 2000, 61, 14-19.

Ramsay G: DNA chips: state-of-the-art. Nature Biotechnol. 1998, 16, 40-44.

Schena M, Heller RA, Theriault TP, Konrad K, Lachenmeier E, Davis RW: Microarrays: biotechnology's discovery platform for functional genomics. Trends Biotech. 1998, 16, 301-306.

Schutz MM: Genetic evaluation of somatic cell scores for United States dairy cattle. J. Dairy Sci. 1994, 77, 2113-2129.
Sharif S, Mallard BA, Wilkie BN, Sargeant JM, Scott $H M$, Dekkers JC, Leslie KE: Associations of the bovine major histocompatibility complex DRB3 (BoLA-DRB3) alleles with occurrence of disease and milk somatic cell score in Canadian dairy cattle. Anim. Genet. 1998, 29, 185-193.

Sharif S, Mallard BA, Wilkie BN, Sargeant JM, Scott $H M$, Dekkers JC, Leslie KE: Associations of the bovine major histocompatibility complex DRB3 (BoLA-DRB3) with production traits in Canadian dairy cattle. Anim. Genet. 1999, 30, 157160

Shook GE: Genetic improvement of mastitis through selection on somatic cell count. Vet Clin. North Am. Food Anim. Pract. 1993, 9, 563-581.

Shook GE, Schutz MM: Selection on somatic cell score to improve resistance to mastitis in the United States. J. Dairy Sci. 1994, 77, 648-658.

Skjervold H: The results of 20 years of selection for production in cattle, sheep, and pigs-which way now? In: Barker JSF, Hammond K, McClintock AE (eds.): Future Developments in the Genetic Improvement of Animals. Academic Press, Toronto, Ontario, Canada. 1982. Pp. 3-14.

Sordillo LM, Shafer-Weaver K, DeRosa D: Immunobiology of the mammary gland. J. Dairy Sci. 1997, 80, 1851-1865.

Strandberg E, Shook GE: Genetic and economic responses to breeding programs that consider mastitis. J. Dairy Sci. 1989, 72, 2136-2142.

Tyler JW, Spears H, Nelson R: Antigenic homology of endotoxin with a coliform mastitis vaccine strain, Escherichia coli 0111:B4 (J5). J. Dairy Sci. 1992, 75, 1821-1825.

Uribe HA, Kennedy BW, Martin SW, Kelton DF: Genetic parameters for common health disorders of Holstein cows. J. Dairy Sci. 1995, 78, 421-430.

Vage DI, Lingaas F, Spooner RL, Arnet, EF Lie O: A study on association between mastitis and serologically defined class I bovine lymphocyte antigens (BoLA-A) in Norwegian cows. Anim. Genet. 1992, 23, 533-536

Van Kampen C, Mallard BA, Wilkie BN: Adhesion molecules and lymphocyte subsets in milk and blood of periparturient Holstein cows. Vet. Immunol. Immunopathol. 1999, 69, 23-32.

Vecht U, Shook GE, Politiek RD, Grootenhuis G, Koops WJ, Groothuis DG: Effect of bull selection for somatic cell count in first lactation on cell counts and pathogens in later lactations. J. Dairy Sci. 1985, 68, 2995-3003.

Wagter LC, Mallard BA, Wilkie BN, Leslie KE, 
Boettcher PJ, Dekkers JC: A quantitative approach to classifying Holstein cows based on antibody responsiveness and its relationship to peripartum mastitis occurrence. J. Dairy Sci. 2000, 83, 488-498.

Waller KP: Mammary gland immunology around parturition. Influence of stress, nutrition and genetics. Adv. Exp. Med. Biol. 2000, 480, 231-245.

Weber PSD, Madsen SA, Smith GW, Ireland JJ, Burton JL: Pre-translational regulation of neutrophil CD62L in glucocorticoid-challenged cattle. Vet. Immunol. Immunopathol. 2001, 83, 213-240.
Yao J, Burton JL, Saama P, Sipkovsky SS, Coussens PM: Generation of EST and cDNA microarray resources for the study of bovine immunobiology. Acta Vet. Scand. 2001, 42, 391-405.

Yao J, Coussens PM, Burton JL, Ernst CW: Development of High Quality cDNA Libraries and Landmarks for cDNA Microarray Study of Complex Disease and Production Traits in Cattle and Swine. Proceedings of the Plant \& Animal Genome IX Meetings, Jan. 13-17, 2001. San Diego, CA (abstract P96, page 78).

(Received August 16, 2001; accepted November 29, 2001).

Reprints may be obtained from JL Burton, Immunogenetics Laboratory and Center for Animal Functional Genomics, Department of Animal Science, 1205E Anthony Hall, Michigan State University, East Lansing, MI 48824 USA. E-mail: burtonj@pilot.msu.edu, tel: Office: (517) 353-9702, fax: (517) 353-1699. 